\title{
Becoming a Stop on the Road to the White House: Using a University Protocol to Govern Candidate Visits
}

\author{
Karen M. Kedrowski, Winthrop University \\ Katarina Duich Moyon, Winthrop University
}

ABSTRACT Winthrop University capitalized upon South Carolina's early presidential primary to bring 10 US Presidential candidates to campus between August 2015 and February 2016. These events are part of Winthrop University's intentional commitment to civic engagement. This essay describes and analyzes how Winthrop University developed a campus-wide protocol for hosting visits by public officials and candidates. It also provides best practices that campuses may emulate in future election cycles.

\section{INTRODUCTION}

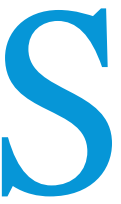

tarting with Robert Putnam (2001), many commentators have decried the declining rates of civic engagement in the United States. While there are varied definitions of civic engagement in the higher education literature, most include civic knowledge and voting as two manifestations of the concept (Jacoby 2009). Voting is also important as the most common form of civic engagement and the bedrock of American democracy. Yet voter turnout in the United States is anemic at best. Since 1965, when the Voting Rights Act eliminated a variety of barriers to voting for African Americans, voter turnout in presidential election years has hovered between $52 \%$ in 1996 to $62.5 \%$ in 1968 . Voter turnout in midterm elections is considerably lower, declining from a high of $47 \%$ in 1970 to $36 \%$ in 2014 (United States Elections Project 2014).

"Millennials," for their part, are less likely to discuss politics and to follow current events than older voters. Voting rates of the youngest voters (ages 18-24) reached an historic low of just $17.1 \%$ in the 2014 midterm election. There are many possible explanations for young adults' lower rates of voter turnout: increased mobility, lack of practice in voting, lack of information about local and statewide races and government structures or registration laws, lower levels of efficacy, higher rates of cynicism, higher rates of voter challenges, and recent election reforms such as shorter early voting periods and voter ID laws (Niemi and Hanmer 2010).

In response, a number of organizations have come together to improve civic learning and engagement among college students (see for instance, Campus Compact 2016; A Crucible Moment 2012).

Karen M. Kedrowski is professor of political science and dean of the College of Arts $\mathcal{E}$ Sciences. She may be reached at kedrowskik@winthrop.edu.

Katarina Duich Moyon is an adjunct professor of political science and director of the Human Experience Program. She may be reached at moyonk@winthrop.edu. Together, they co-direct the John C. West Forum on Politics and Policy, a civic engagement initiative at Winthrop University.
The Fair Elections Legal Network, a nonpartisan nonprofit advocacy group dedicated to reducing barriers to voting, has identified a number of "best practices" through its Campus Vote Project. They include providing voter registration information in freshmen orientation or residence hall move-in packets, participation in the Tufts University's National Study of Learning, Voting, and Engagement (NSLVE) study, distribution of voter registration and election information through social media, holding candidate forums, and more (Campus Vote Project 2016).

Implicit in these best practices, especially the directive to host issues and candidate forums, is that voters need information, particularly first time voters. With more information, students will be more likely to engage in the election process and to vote. With this in mind, Winthrop University embarked on a two-year process to plan for and host a series of presidential candidate visits in advance of the 2016 presidential primary season. This planning process, complete with the development of a University-wide protocol, can be emulated by institutions across the country.

\section{BACKGROUND}

Winthrop University is a regional, public, master's level institution of 6,0oo students in Rock Hill, South Carolina. The University has slowly built its capacity to host prominent candidate visits. In 2004, one presidential candidate, Alan Keyes (R) and one vice presidential nominee, Mary Alice Herbert of the Socialist Party, visited campus. In 2008, the number grew to five major party candidates. In 2012, eight GOP hopefuls and the Libertarian presidential nominee came to Winthrop. Collectively, these experiences enabled University personnel to gain valuable experience in working with national campaigns, the Secret Service, the national press corps, and local political leaders and they set the stage for the 2016 election cycle.

In 2016 Winthrop University hosted a total of 13 primaryrelated candidate visits to the campus (some candidates came to Winthrop for more than one event). Many made campaign 
stops or held rallies, but others (Bush, Huckabee, Paul) held "town-hall-style" events with prominent statewide elected officials or media personalities. Both parties held one major event on campus: MSNBC and the South Carolina Democratic Party held the First in the South Democratic Forum. Host Rachel Maddow interviewed the three final Democratic candidates (Clinton,
The following subjects were included in the protocol: event sponsorship; communication with candidates and campaign staff; cultural event designation; ${ }^{1}$ communicating institutional neutrality; facilities, equipment, IT, catering, and set up; media relations; security and parking; community participation; and cost sharing.

\section{...Winthrop University embarked on a two-year process to plan for and host a series of presidential candidate visits in advance of the 2016 presidential primary season. This planning process, complete with the development of a University-wide protocol, can be emulated by institutions across the country.}

Sanders, O'Malley) one by one on stage in front of a live audience of 3,00o people. On the Republican side the Carolinas Values Summit held a forum where David Brody, journalist for the Christian Bible Network, interviewed two candidates and a stand-in (Carson, Cruz, and Santorum who was representing Rubio's campaign). In all events, the audience size ranged from 350-5,500 people.

Although not every institution is located in an early primary state, primary contests in 2008, 2012, and 2016 have stretched far into the spring, providing opportunities for campuses in dozens of states to host presidential candidates. Every state also hosts statewide elections for governor or US senate, providing excellent opportunities for institutions, led by political science faculty with scholarly interest in civic engagement, to become involved in the election process. Additionally, institutions seeking to build capacity could begin with US House of Representatives or state legislative races, or focus on other statewide offices that may be of interest to students, for example the state Superintendent of Education. Beginning at this level also helps the institution build relationships with the state parties.

\section{CREATING AND UTILIZING A CANDIDATE VISIT PROTOCOL}

Winthrop University took a systematic approach toward the 2015-16 primary election cycle. The University's goal was to maximize student learning and participation in the primaries as well as to involve the campus and the wider community in civic engagement. A crucial component to this success was the development of the Candidate Visit Protocol. In 2013, eight university faculty and staff worked together to create a campus-wide protocol for handling all types of political and election-related events. The intention was to use the 2014 midterm elections as a means to test and adjust the protocol as needed in advance of the 2016 primary season. The group included all parties who would be directly impacted by candidate visits-campus police (for security and parking); political science faculty (for classroom tie-ins and media commentary); the president's office (to communicate institutional commitment); university events (for securing space, furnishings, catering and the like); media relations staff (to interact with reporters and track and record events for the university); building managers (who supervise and coordinate set up); and co-directors of the West Forum, one of the University's civic engagement initiatives. The University-wide protocol is a living document that continues to be amended as needs arise (Winthrop University 2013).
The group agreed that different protocols were required for especially prominent officials and candidates (governor, US senators and representatives, and presidential candidates) than for other officials and candidates. The protocol committee determined appropriate university offices to be contacted in the case of each type of event based on the prominence of each candidate. The protocol also included information about the IT and media equipment in each of the major campus spaces; catering contact information; media advisory timing and content guidelines; video- and audio-taping guidelines; and costs that would be charged to the campaign or be borne by the University. Perhaps most importantly, members of this group became personally acquainted and understood each person's role in the University.

This protocol helped focus the campus's response as candidates' requests came in. Past experience indicated that one could not predict how a candidate's campaign might approach the University. In 2016, one candidate's campaign initiated contact through the catering office, for example. The protocol helped anyone who received an inquiry to route the request to the appropriate office or department. Candidates for the highest offices (governor, US senators, US representatives, US presidential candidates) were directed to the President's Office. Candidates and officials in lower level offices were directed to the political science department, for instance.

\section{Communicating Institutional Neutrality}

The protocol also established means to maintain the institution's ideological neutrality and nonpartisanship. The University did so in several ways. First the institution did not officially sponsor partisan events like campaign rallies; such events were sponsored by student organizations, even if the University handled many of the logistics. Second, the protocol stipulated rules for campaign literature and staffing. No university logos would be placed on tables used for sign ups and literature. Such tables would be staffed by campaign volunteers or staff, not Winthrop personnel. Winthrop University personnel who were working an event would wear official nametags, attire, and/or credentials to differentiate them from the campaign staff. Third, the University strived to treat all campaigns and candidates as similarly as possible. Finally, the protocol clearly established that all media releases would include the following statement:

Winthrop University is a public institution dedicated to serving the state of South Carolina and to promoting the free exchange 
of ideas and informed citizenship. Thus Winthrop University welcomes political candidates, elected officials, and guest speakers from all partisan and ideological perspectives to visit campus and present their ideas to the Winthrop and Rock Hill communities. These appearances do not constitute an endorsement of any party, candidate, or ideological perspective (Winthrop University 2013).

\section{Defining Cost-Sharing}

A second crucial detail spelled out in the protocol are costs. In Winthrop's case, the University's contribution to the presidential candidate visits was to donate the space and personnel time during regular working hours. The University also purchased some minor equipment, such as a "mult box" and a "step and repeat," a backdrop for faculty providing media commentary. Campaigns generalizable to any campus seeking to host prominent officials and candidates.

\section{Start small}

Hosting a presidential candidate visit is a lot of work and there are lots of moving parts. Consider hosting a state-level debate, such as between gubernatorial candidates, before moving onto the national stage, to get some practice.

\section{Determine how to incentivize and reward faculty participation}

If a university is successful in its efforts, candidate campaign stops can snowball during election season. To keep faculty actively engaged in this process, faculty need incentives and/or

\section{The protocol also established means to maintain the institution's ideological neutrality and nonpartisanship.}

were expected to pay for any other costs, such as overtime, catering, and damages, if necessary. Although the University offered its space free of charge for the events, the University maintained final decision-making authority over how the spaces would be used.

\section{Utilizing On-Campus Expertise}

Winthrop University realizes that it is competing with other venues, including other universities, for campaign events. Therefore, the protocol defines how an event at Winthrop had added value for campaigns and news media alike. The University pledged to provide at least one faculty expert who would be available for news media commentary and interviews after each event. Political science faculty became the core of the group who provided this color commentary. This also helped raise the University's profile in the news media generally.

\section{Keeping "No" as an Option}

The protocol stipulates that Winthrop University may decline to host a candidate or event at its discretion. Possible reasons include an inability to provide security, conflict with other major University events, and/or no appropriate space. This provision was not utilized but it did ensure to any interested parties that Winthrop may not be able to accommodate all requests. Any institution embarking on such efforts should decide for itself whether it will accept a request from the American Nazi Party and/or the American Communist Party. If it does, can it handle protestors and counter protesters?

The protocol was crucial to the year's success, especially because it carried the support of the President's Office. For instance, when a state legislator contacted the President's office to complain that a particular candidate's appearance event was not an approved cultural event, the staff member who responded could refer to the relevant passage in the protocol about what type of events constitute cultural events.

\section{Other Generalizable Lessons}

In addition to developing a candidate visit protocol, Winthrop University personnel learned a number of lessons that are rewards to participate in numerous events. Possible incentives include stipends for participating in media interviews, working such service into the institution's tenure and promotion documents, or nomination for special campus awards or recognition.

\section{Define student impact broadly}

Increasing students' political engagement and voting is the objective, so consideration should be given to including students from a wide variety of disciplines. When faculty include different aspects of the events in their coursework, or university personnel otherwise incentivize students to attend, the impact will be much more widely dispersed.

\section{Be nimble}

Campaigns are often making decisions on the fly. Expect things to change at the last minute.

\section{Welcome protesters}

Have consistent rules about protestors within events, enforce these rules vigorously in all cases, and designate an area for protestors outside each venue.

Hosting presidential candidates is consistent with the Campus Vote Project's "best practices" to encourage student voting. Students enrolled in political science and mass communication courses especially benefitted from learning opportunities stemming from the presidential candidate visits. Similarly, these events and other secondary events generated excitement and conversation on the campus and in the community. The events also generated a broader, campus-wide discussion about freedom of speech, particularly after protesters were escorted out of a rally for Republican candidate Donald Trump.

The ultimate measure of the effectiveness of hosting candidate visits would be to see higher than expected voter turnout rates among Winthrop University students. However, determining this is very difficult. Statewide, young voters (ages 17-24) comprised only $5 \%$ of the Republican primary voters and $7 \%$ of the Democratic primary voters (CNN 2016). However, determining whether Winthrop University students turned out at higher rates 
than their peers is exceedingly difficult. Checking campus voter precinct numbers is not accurate due to the high number of students who register and vote elsewhere. Self-reporting notoriously exaggerates actual turnout and the most reliable measure, the NSVLE study, focuses on general elections, not primaries. Thus, we must rely on indirect measures of this effort's success-student attendance, awards, internships, learning experiences, and media appearances-all of which indicate that the presidential candidate appearances on campus did provide a civic education function to students, and an incentive to turn out to vote.

\section{ACKNOWLEDGMENTS}

We thank the editors of $P S$ and an anonymous reviewer for their helpful comments on an earlier version of this essay.

\section{NOTE}

1. Winthrop University undergraduate students need to attend a minimum of 18 approved "cultural events" as a graduation requirement. These include theatre dance, and musical performances; gallery talks; and public lectures on timely issues. Under the University's guidelines, campaign events are not eligible for cultural events status; however, town halls and appearances by elected official might be approvable under certain circumstances.

\section{REFERENCES}

Campus Compact. 2016. "Who We Are." Available: http://civicyouth.org/ 2014-youth-turnout-and-youth-registration-rates-lowest-ever-recorded-changesessential-in-2016/. Accessed May 24, 2016

Campus Vote Project. 2016. "Best Practices to Help Students Register and Vote: A Guide to Colleges and Universities.” Available: http://campusvoteproject.org/ wp-content/uploads/2015/o6/Best-Practices-for-Colleges-and-Universities2015.pdf. Accessed May 24, 2016.

CNN. 2016. South Carolina Exit Polls. Available http://www.cnn.com/election/ primaries/polls/sc/Dem and http://www.cnn.com/election/primaries/polls/sc/Rep. Accessed June 28, 2016

Jacoby, Barbara and Associates. 2009. Civic Engagement in Higher Education Concepts and Practices. San Francisco: John Wiley and Sons.

National Task Force on Civic Learning and Democratic Engagement, The. 2012. A Crucible Moment: College Learning and Democracy's Future. Washington, DC: AAC\&U.

Niemi, Richard G. and Michael J. Hanmer. 2010. "Voter Turnout Among College Students: New Data and Rethinking of Traditional Theories." Social Science Quarterly 91 (2): 301-323.

Putnam, Robert D. 2001. Bowling Alone: The Collapse and Revival of the American Community. New York: Simon and Schuster.

United States Elections Project. 2014. "National General Election VEP Turnout Rates, 1789-Present.” Available: http://www.electproject.org/national-1789present. Accessed May 22, 2016.

Winthrop University. 2013. "Candidate Visit Protocols: 2014-2016 Election Cycles.” Available: https://www.winthrop.edu/uploadedFiles/artscience/ CandidateVisitProtocols2014-16.pdf. Accessed June 28, 2016. 